\title{
Institutional priorities and faculty rewards update
}

The June 1997 issue of CERL News included the draft statement prepared by the ACRL Institutional Priorities and Faculty Rewards Task Force (pp. 414-18). The statement is intended to be ACRL's contribution to the national Institutional Priorities and Faculty Rewards project, an initiative involving almost two dozen disciplinary associations to date. In addition to comments on the draft gathered from ACRL members via e-mail, the task force solicited feedback at a hearing held on June 28,1997 , at the ALA Annual Conference in San Francisco. Suggestions focused primarily on concerns that (a) the document might unintentionally imply that all of the functions described should be expected of all librarians, and (b) the document appeared to place ton much emphasis on teaching and not enough on the range of activities often found in promotion and tenure policies under the category "Librarianship."

The task force has modified the draft statement in an attempt to address these concerns and has forwarded the revised document to be placed on the ACRL Web page (http:/ www.ala.org/acrl.html). Those without Wel access may obtain a printed copy of the revised statement from the task force chair, $W$. Bede Mitchell, Belk Library, Appalachian State Iniversity, Boone, NC 28608; MITCHELIWB @APPSTATE.EDU. The task force intends to submit its final report to the ACRL Board of Directors at the Midwinter Meeting in New Orleans. The task force invites further suggestions and comments on the statement, which should be forwarded to the task force chair.

Established by Syracuse University's Center for Instructional Development and funded

Other institutions with SIRSI systems are Stanford University, Carnegie Mellon University, the University of Virginia, and Emory University.

\section{Ten more libraries pick UnCover's Gateway}

Clemson, East Cárolina, Florida Gulf Coast, Kansas State, Lehigh. Southern, and Louisiana Tech- by the Lilly Endowment with support from the Fund for the Improvement of Postsecondary Education, the Institutional Priorities and Faculty Rewards project aims to extend the range of faculty activities that are rewarded through promotion, tenure, and merit. Each disciplinary association is responsible for drafting a statement defining and describing the range of work performed by faculty in the discipline, including many activities that are often not adequately recognized within the traditional "publish or perish" paradigm. The first set of these statements may be found in The Disciplines Speak: Rewarding the Scholarly, Professional, and Creative Work of Faculty, edited by Rolsert M. Diamond and Bronwyn F. Adam (American Association for Higher Eiclucation, 1995).

Subsequent to the ALA Annual Conference, task force chair W. Bede Mitchell (Appalachian State Iniversity) and member Carol Parke (Syracuse University) represented ACRL at the Institutional Priorities and Faculty Rewards Summer Conference, July 17-20, 1997. In addition to hearing progress reports on the next round of disciplinary statements now being prepared. the conference attendees from more than a dozen of the project's participating clisciplinary associations began working on guidelines for administrators, faculty, and col lective bargaining agents who are involved in developing promotion, tenure, and merit pay policies. The guidelines are intended for eventual publication and will focus on policies, procedures, and criteria by which faculty should be evaluated in light of the work done by the disciplines participating in the Institutional Priorities and Faculty Rewards project.-W. Bede Mitchell, Appalachian State Unin'ersity

nical Universities, Monterey Bay Aquarium and Research Institute, Rennselaer Polytechnic Institute, and the University of Notre Dame have selected the UnCover Company's Gateway system. Libraries subscribing to the system can match their serials holdings with the UnCover database collection of 17.000 journal titles. This customized database can then be accessed by patrons using a powerful new Web-lyased in- 